\title{
Follow-up of copper intrauterine device insertion by nurses: a prospective longitudinal study
}

\author{
Acompanhamento da inserção de dispositivos intrauterinos de cobre por enfermeiros e médicos: \\ estudo longitudinal prospectivo
}

Seguimiento de la inserción de Dispositivos Intrauterinos de cobre por enfermeros: un estudio longitudinal prospectivo

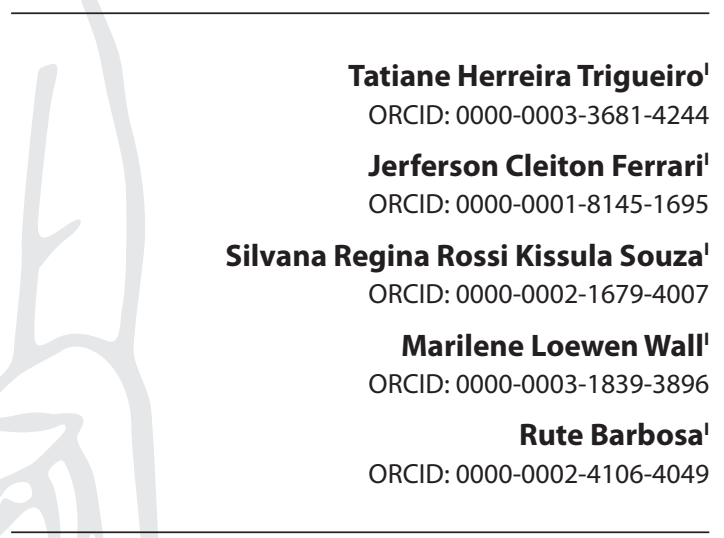

'Universidade Federal do Paraná. Curitiba, Paraná, Brazil.

How to cite this article:

Trigueiro TH, Ferrari JC, Souza SRRK, Wall ML, Barbosa R. Follow-up of copper intrauterine device insertion by nurses: a prospective longitudinal study.

Rev Bras Enferm. 2020;73(Suppl 4):e20200156. doi: http://dx.doi.org/10.1590/0034-7167-2020-0156

Corresponding author:

Tatiane Herreira Trigueiro

E-mail: tatiherreira@gmail.com

EDITOR IN CHIEF: Antonio José De Almeida Filho ASSOCIATE EDITOR: Ana Fátima Fernandes

Submission: 05-25-2020 Approval: 08-03-2020

\section{ABSTRACT}

Objective: to assess the complications, acceptability and causes of discontinuation of women who inserted copper intrauterine devices at a usual risk maternity for one year. Methods: a longitudinal-prospective study, lasting 12 months. Eighty-three women who received the device by a doctor or nurse in a maternity hospital between September and October 2017 participated. Data were collected at one, six and 12 months after insertion and underwent descriptive analysis. Results: most were inserted by nurses and 71 continued with the device. Women chose IUD use because there is no risk of forgetfulness, it is non-hormonal and effective. The 12 who discontinued use reported dysmenorrhea, menorrhagia, irregular bleeding, fall out, and endometrium perforation. Conclusion: the method was continued by most of participants and the complications found are common to the literature. There is a need to expand nursing training to increase the offer to the population.

Descriptors: Nurses; Intrauterine Devices; Women's Health; Family Planning Policy; Professional Autonomy.

\section{RESUMO}

Objetivo: levantar as intercorrências, aceitabilidade e causas de descontinuação de mulheres que inseriram o Dispositivo Intrauterino de cobre em uma maternidade de risco habitual por um ano. Métodos: estudo longitudinal-prospectivo, com duração de 12 meses. Participaram 83 mulheres que receberam o dispositivo por médico ou enfermeiro na maternidade entre setembro e outubro de 2017. Os dados foram coletados com um, seis e 12 meses da inserção. Os dados passaram por análise descritiva. Resultados: a maioria foi inserida por enfermeiros; 71 continuaram com o dispositivo e os motivos de escolha foram por não ser hormonal, por não haver risco de esquecimento e por ser eficaz. As 12 que não prosseguiram relataram dismenorreia, menorragia, sangramentos irregulares, expulsão ou perfuração do endométrio. Conclusão: houve continuidade do método pela maioria das participantes, e as intercorrências encontradas são comuns à literatura. Há necessidade da ampliação da capacitação para enfermeiros, para aumentar a oferta à população.

Descritores: Enfermeiros; Dispositivos Intrauterinos; Saúde da Mulher; Planejamento Familiar; Autonomia Profissional.

\section{RESUMEN}

Objetivo: relevar las complicaciones, aceptabilidad y causas de interrupción de las mujeres que insertaron el dispositivo intrauterino de cobre en una maternidad de riesgo habitual durante un año. Métodos: estudio longitudinal-prospectivo de 12 meses de duración. Participaron 83 mujeres que recibieron el dispositivo por parte de un médico o enfermero en la maternidad entre septiembre y octubre de 2017. Los datos se recolectaron al mes, seis y 12 meses después de la inserción. Los datos se sometieron a análisis descriptivo. Resultados: la mayoría fueron insertados por enfermeras; 71 continuó con el dispositivo y las razones para elegirlo no fueron hormonales, no hubo riesgo de olvido y fue efectivo. Las 12 que no continuaron refirieron dismenorrea, menorragia, sangrado irregular, expulsión o perforación del endometrio. Conclusión: hubo continuidad del método por la mayoría de los participantes, y las complicaciones encontradas son comunes a la literatura. Es necesario ampliar la formación de enfermeras para incrementar la oferta a la población.

Descriptores: Enfermeros; Dispositivos Intrauterinos; Salud de la Mujer; Planificación Familiar; Autonomía Profesional. 


\section{INTRODUCTION}

In Brazil, Law 9,263, of January 12, 1996 deals with family planning and defines the State's responsibility to provide educational and scientific conditions and resources so that men and women have access to information, means, methods and techniques for fertility regulation. Fertility control is related to an exercise of the woman's power over her body, in order to avoid unplanned pregnancies ${ }^{(1)}$. Currently, the term "family planning" has been replaced by "reproductive planning"(2).

According to a nationwide survey of 23,894 mothers, it was found that approximately $30 \%$ did not plan the current pregnancy, 9\% were dissatisfied with the news of their pregnancy and $2.3 \%$ tried to terminate $\mathrm{it}^{(3)}$. A research carried out with pregnant women registered in the Family Health Strategy teams in the municipality of Montes Claros, Minas Gerais State, found that of the 394 pregnant women interviewed, 58.9\% (232) had not planned pregnancy, were aged between 13 and 46 years, with average of 24.7 years and higher prevalence in the age group between 25 and 29 years old (28.4\%), followed by 13 and 19 years old $(25.4 \%)^{(4)}$.

In order to reduce the rates of unplanned pregnancies and reinforce actions aimed at reproductive planning by Brazilian women, the government provides several types of contraceptive methods, one of which are Copper Intrauterine Devices (IUDs), the TCu380A ${ }^{(5)}$.

Copper IUDs are effective for up to 12 years; however, use for 10 years is recommended. Their contraceptive action is summarized in a local inflammatory reaction caused by biochemical and morphological changes that produces minimal endometrial tissue damage capable of rendering the environment sterile, altering the cervical mucus and having spermicidal action ${ }^{(6)}$. As for its effectiveness, the World Health Organization (WHO) claims to be $99.4 \%$, i.e., from the correct use, the probability of pregnancy is around $0.6 \%$, and fertility is immediately reversible after its removal ${ }^{(7)}$.

According to the Manual of Medical Criteria for eligibility for contraceptive use, copper IUDs is indicated for both nulliparous and multiparous women after vaginal or cesarean delivery; after abortion in the first trimester; for women who have contraindications for hormone use such as smokers, obese, with a history of breast cancer and in the family ${ }^{(8)}$.

The performance of nurses stands out, with a view to reproductive planning, which occurs through knowledge and implementation of existing health policies in the country and municipality; engagement in health education; search for technical-scientific knowledge regarding the best scientific evidence. Their practice should be aimed at guaranteeing women's sexual and reproductive rights at different levels of care.

Giving attention and incorporating reproductive planning in nurses' daily practice and care practice is supported by the Professional Exercise Law 7,498 ${ }^{(9)}$ of June 25, 1986, through Nursing Consultation, Systematization of Nursing Care, and Nursing Process, provided for in COFEN (Conselho Federal de Enfermagem - Federal Nursing Council) Resolution 358 ${ }^{(10)}$ of October 15, 2009, be it in primary care as well as on an outpatient and hospital level.

Therefore, if a woman chooses to have a copper IUD and is in clinical compliance with her current health condition, in addition to insertion by a physician, Technical Opinion 17 of November 11,2010 , published by COFEN, points out that, as long as they receive proper training, there is no legal impediment for nurses to also insert IUDs to SUS users ${ }^{(11)}$. It should be noted that since 2013 WHO recommends that nurses are allowed to insert and remove IUDs, as this practice can help to reduce inequalities in care for the most needy populations ${ }^{(12)}$.

Thus, based on the above and because the regulation of IUD insertion by nurses is in constant legal discussion, conducting research that addresses this practice by this professional is justified.

\section{OBJECTIVE}

This study aimed to assess the complications, acceptability and causes of discontinuation of women who inserted copper intrauterine devices at a usual risk maternity for one year.

\section{METHODS}

\section{Ethical aspects}

The research was developed according to Resolution 466/2012 of the Brazilian National Health Council (Conselho Nacional de Saúde)/Ministry of Health and approved by the Research Ethics Committee of the local hospital for data collection.

\section{Design, period, and place of study}

This is a longitudinal-prospective study, according to STROBE guidelines. It was developed in a usual risk maternity hospital in the city of Curitiba, Paraná. IUD insertions in the maternity clinic are performed by physicians and nurses for women treated in the late postpartum period and for those who opted for IUD as a contraceptive method, without necessarily having their births in a maternity hospital. As an institutional routine, motherhood recommends that women return for follow-up consultation 30 to 40 days after placing the Device in an outpatient clinic. It should be noted that the average number of insertions per month is 50 procedures.

\section{Population or sample; inclusion and exclusion criteria}

All women who performed the insertion of this method between the months of September and October 2017 were selected, totaling 90 ; however, after one month of insertion, there is a need to return to the clinic for routine consultation. Of these, seven did not attend the return visit; therefore, of the 83 women who attended, all were invited to participate in the study and accepted it.

Women over 18 years of age, who received IUD either in the immediate postpartum period or outside this period, who had the IUD inserted by a physician or nurse and attended the first return to the maternity hospital one month after insertion have been included. Those who did not have a subsequent telephone contact through three attempts would be excluded; however, in this study, there was no exclusion.

\section{Study protocol}

Woman gathering was carried out during the return visit, after a month of insertion, between September and October 2017, where the study was explained, and participation was 
consolidated by signing the Informed Consent Form (ICF) in two copies. After selection, they were instructed that they would receive a call after six months and another after 12 months after the copper IUD insertion to complete the study. The six-month connection took place between March and May 2018 and with 12 months between September and October 2018.

The data were collected through a form prepared by the researchers, containing the following data: identification, education, date of insertion, place of insertion in maternity ward (obstetric or ambulatory center), age, telephone for later contact, number of pregnancies, person responsible by insertion. Contact after six and twelve months had the same questions as script, such as contraceptive method prior to IUD, reason for choosing the method, if there was fall out, removal, contraceptive failure, continuation, causes of discontinuation, moment of discontinuation, complaints and compliments.

\section{Analysis of results, and statistics}

Participants' answers were tabulated and coded in a database in spreadsheet format. For data interpretation, quantitative descriptive analysis was used, which are organized in tables, graphs, and charts.

\section{RESULTS}

A total of 83 women participated in the survey. Of these, 82 inserted the IUD in a maternity clinic, and only one in a obstetric center. The age of the participants ranged from 18 to 42 years, with an average of 26.3 years. As for education, the majority (53\%) had completed high school, and attention was drawn to the number of women who were attending or finished higher education, representing $38 \%$ of the sample. Concerning gestational history, the most frequent were secondary (38.6\%), primiparous (33.7\%) and nulliparous (19.3\%). As for type of delivery, except for nulliparous women, 52 (62.7\%) had at least one vaginal delivery.

Table 1 - Sample characterization according to age, education, number of pregnancies and reproductive planning, Curitiba, Paraná, Brazil, 2018

\begin{tabular}{|c|c|c|c|c|c|c|}
\hline \multirow{3}{*}{ Variables } & \multicolumn{4}{|c|}{ IUD permanence } & \multirow{2}{*}{\multicolumn{2}{|c|}{ Total }} \\
\hline & \multicolumn{2}{|c|}{ Yes } & \multicolumn{2}{|c|}{ No } & & \\
\hline & $\mathbf{n}$ & $\%$ & $\mathbf{n}$ & $\%$ & $\mathbf{n}$ & $\%$ \\
\hline \multicolumn{7}{|l|}{ Age } \\
\hline 18 to 29 years & 51 & 61.5 & 8 & 9.6 & 59 & 71.1 \\
\hline 30 to 39 years & 18 & 21.7 & 3 & 3.6 & 21 & 25.3 \\
\hline Above 40 & 2 & 2.4 & 1 & 1.2 & 3 & 3.6 \\
\hline Average: 26.3 years. & & & & & & \\
\hline \multicolumn{7}{|l|}{ Education } \\
\hline Elementary School & 5 & 6.0 & 0 & 0 & 5 & 6.0 \\
\hline High school & 42 & 50.6 & 8 & 9.6 & 50 & 60.2 \\
\hline Higher education & 24 & 28.9 & 4 & 4.8 & 28 & 33.7 \\
\hline \multicolumn{7}{|l|}{ Number of pregnancies } \\
\hline 0 (nulliparous) & 14 & 16.9 & 2 & 2.4 & 16 & 19.3 \\
\hline 1 to 2 & 52 & 62.7 & 8 & 9.6 & 60 & 72.3 \\
\hline 3 or more & 5 & 6.0 & 2 & 2.4 & 7 & 8.4 \\
\hline \multicolumn{7}{|l|}{$\begin{array}{l}\text { Reproductive planning } \\
\text { (Pre-IUD method) }\end{array}$} \\
\hline Hormonal * & 42 & 50.6 & 7 & 8.4 & 49 & 59.0 \\
\hline Barrier** & 13 & 15.7 & 3 & 3.6 & 16 & 19.3 \\
\hline IUD & 4 & 4.8 & 0 & 0 & 4 & 4.8 \\
\hline None & 12 & 14.5 & 2 & 2.4 & 14 & 16.9 \\
\hline
\end{tabular}

Concerning the contraceptive method used prior to IUD, the majority (43.4\%) of participants stated that they combined oral contraceptives, followed by male condom use by their partner, monthly injectable contraceptives, IUD, emergency contraception. A total of 14 (16.9\%) stated that they did not use any contraceptive method. The information regarding sample characterization is summarized in Table 1.

Of the professionals responsible for insertion, 32 (38.6\%) of them had the IUD inserted by physicians, and 51 (61.4\%) of them, by nurses. Regarding the reasons for choosing the method, 56 (67.5\%) participants stated that they chose copper IUD because it was a non-hormonal method and 20 (24.1\%) chose it because there was no risk of forgetting to administer it. Other responses included were for being an easy and practical method (three participants $-3.6 \%$ ), safe (two participants $-2.4 \%$ ), due to failure in the previous method (one participant - $1.2 \%$ ), or due to contraindication hormone use (one participant - 1.2\%).

In the return to maternity consultation one month after the insertion, 58 women (69.9\%) did not present any complications. When asked about the adaptation to the method, four (4.8\%) stated good adaptation; 14 (16.9\%) reported dysmenorrhea; four (4.8\%) had menorrhagia; four (4.8\%) had bacterial vaginosis; one $(1.2 \%)$ reported dyspareunia. The four participants who had bacterial vaginosis underwent the recommended treatment and continued use.

At the six-month follow-up, it was found that 72 women (86.7\%) continued with their IUD and 11 women (13.3\%) reported discontinuing use. Concerning complications (Chart 1), among women who did not continue using IUD after six months, one (1.2\%) had her IUD fallen out two months after inserting the device, presented dysmenorrhea and menorrhagia, but said that she intends to perform retry insertion.

Of the remaining 10 users (12.1\%) who experienced complications and chose or had to have their IUD removed, five (6.0\%) reported irregular bleeding as causes of discontinuation, removing the device between two and six months after insertion; four (4.8\%) reported not having adapted to the method due to the initial side effects, such as dysmenorrhea and menorrhagia and/ or headache, removing the device between two and five months after insertion; and one (1.2\%) had endometrial perforation two months after insertion.

Of the participants who did not continue with the method after six months, five were inserted by physicians and six by nurses. None reported contraceptive failure with regard to IUD use. As for complications, most occurred in the first six months. After a fllow-up carried out during this period, only one more user reported removal due to non-adaptation to the side effects that did not cease. Thus, at the end of 12 months of follow-up, the complications presented by women who did not continue with the method were fall out, observed in one participant, and removal, observed in 11 participants. Thus, in the follow-up over 12 months of insertion, most women still continued with the method and 12 (14.5\%) of them reported discontinuation of use. The majority (62.7\%) reported good acceptance and adaptation to the method, as can be seen in Table 2 .

As to the causes of discontinuation over the 12 months, it was observed that five (6.0\%) occurred due to irregular bleeding; five 
(6.0\%) reported not having adapted to the method due to the initial side effects, such as dysmenorrhea and menorrhagia and/ or headache; one (1.2\%) had her IUD fallen out; one (1.2\%) had endometrium perforation. A total of 71 (85.5\%) women continued with the method. Concerning professionals responsible for IUD insertion, among women who continued with the device, 27 (32.5\%) were inserted by physicians and 44 (53.0\%) by nurses, as shown in Table 3.

Table 2 - Complications after 12 months using IUD, Curitiba, Paraná, Brazil, 2018

\begin{tabular}{lcccccc} 
& \multicolumn{2}{c}{ First month } & \multicolumn{2}{c}{$\mathbf{6}$ months } & \multicolumn{2}{c}{$\mathbf{1 2}$ months } \\
& $\mathbf{n}$ & $\mathbf{\%}$ & $\mathbf{n}$ & $\mathbf{\%}$ & $\mathbf{n}$ & $\mathbf{\%}$ \\
\hline Fall out & - & - & 1 & 1.2 & 1 & 1.2 \\
Removal & - & - & 10 & 12.1 & 11 & 13.3 \\
Failure & - & - & - & - & - & - \\
Continuation & 83 & 100.0 & 72 & 86.7 & 71 & 85.5 \\
Total & 83 & 100.0 & 83 & 100.0 & 83 & 100.0 \\
\hline
\end{tabular}

There was a predominance of nurse practitioners in performing the procedure with more than half of the insertions. As for the 12 women who had complications and discontinued use, five (6.1\%) were inserted by physicians, and seven ( $8.4 \%)$, by nurses. Thus, there is no significant difference regarding the professional who performed IUD insertion related to complications.

Table 3 - Professionals responsible for IUD insertion, Curitiba, Paraná, Brazil, 2018

\begin{tabular}{lcccccc}
\hline & \multicolumn{2}{c}{ Physicians } & \multicolumn{2}{c}{ Nurses } & \multicolumn{2}{c}{ Total } \\
& $\mathbf{n}$ & $\%$ & $\mathbf{n}$ & $\%$ & $\mathbf{n}$ & $\%$ \\
\hline Continuation & 27 & 32.5 & 44 & 53.0 & 71 & 85.5 \\
Discontinuation & 5 & 6.1 & 7 & 8.4 & 12 & 14.5 \\
Total & 32 & 38.6 & 51 & 61.4 & 83 & 100.0 \\
\hline
\end{tabular}

In contact with the participants at 12 months after IUD insertion, some reported that some side effects ceased or decreased; however, some of them still had complaints. The most frequent was dysmenorrhea, followed by menorrhagia and irregular bleeding outside the menstrual period. It is worth mentioning that 47 (56.6\%) users did not report any complaints after 12 months. These data are presented in Table 4 below:

Table 4 - Complaints reported by participants after 12 months of using IUD, Curitiba, Paraná, Brazil, 2018

\begin{tabular}{lcc}
\hline Complaint & $\mathbf{n}$ & $\%$ \\
\hline Dysmenorrhea & 29 & 34.9 \\
Menorrhagia & 20 & 24.1 \\
Irregular bleeding & 9 & 10.8 \\
Headache & 3 & 3.6 \\
Dyspareunia & 1 & 1.2 \\
Decreased libido & 1 & 1.2 \\
Not adapted & 1 & 1.2 \\
Little-publicized method & 1 & 1.2 \\
None & 47 & 56.6 \\
Total & 36 & 43.4 \\
\hline
\end{tabular}

Although there are still complaints regarding the method at 12 months, it is observed that dysmenorrhea, menorrhagia and irregular bleeding have decreased. However, women who experienced some complications or reported fewer common complaints remained with the same report. After 12 months of use, there were 20 users less that reported any complaints in relation to the first six months of follow-up. This fact reveals that the main side effects occurred in the first months of use and adaptation occurred gradually until the end of first year of insertion.

Concerning compliments (Table 5), in contact after 12 months of IUD insertion, most participants reported good adaptation to the method; they complimented the fact that it was not hormonal; would recommend it to other women; they find IUD safe and reliable; some reported that they liked the method; they find it effective and complimented that there is no risk of forgetting administration; however, five of them did not give any compliment.

Table 5 - Compliments by participants after 12 months using IUD, Curitiba, Paraná, Brazil, 2018

\begin{tabular}{lcc}
\hline Compliment & $\mathbf{n}$ & $\%$ \\
\hline Good adaptation & 52 & 62.7 \\
Non-hormonal & 47 & 56.6 \\
Recommended the method & 46 & 55.4 \\
Safe/reliable & 31 & 37.3 \\
Liked the method & 22 & 26.5 \\
Effective & 21 & 25.3 \\
There is no risk of forgetting administration & 18 & 21.7 \\
Decreased symptoms of premenstrual tension & 3 & 3.6 \\
Decreased migraine & 1 & 1.2 \\
Regulated cycle & 1 & 1.2 \\
Assisted in weight loss & 1 & 1.2 \\
None & 5 & 6.0 \\
Total & 78 & 94.0 \\
\hline
\end{tabular}

Upon contact with 12 months to complete the study, participants were asked if they were satisfied with their IUDs and 75 women (90\%) said yes, and only eight participants (10\%) were not satisfied with the device.

It was observed that the number of women who reported not being satisfied with the method is lower than the number of women who had complications and did not continue with the same method. It is noted, as aforementioned, that even some who had to discontinue use reported being satisfied. Thus, of the 12 who no longer use it, four of them said that they liked the method and intend to insert it again in the future.

\section{DISCUSSION}

Copper IUD insertion by nurses is a practice already performed and consolidated in several countries, such as England(13), the United States ${ }^{(14)}$, Australia ${ }^{(15)}$, India ${ }^{(16)}$, among others, in addition to being a practice recommended by $\mathrm{WHO}^{(12)}$. In this study, we have observed a predominant productivity of nurse practitioners.

A case-control study conducted in India compared postpartum IUD insertion performed by physicians and nurses, concluded that trained nurses who perform the procedure do so as safely as physicians and do not compromise the quality of service ${ }^{(16)}$. This fact reinforces the findings of this study, since there was no significant difference regarding complications related to insertion by physicians or nurses.

North American nurse practitioners excel in handling rates of unplanned pregnancies. In this regard, they provide reversible 
long-acting contraceptive methods to the population, including copper IUDs, whose insertion is part of nursing care practice ${ }^{(14)}$.

In Australia, nursing training for IUD insertion has been taking place since 2012. In a study carried out in this country, 207 insertions performed by nurses were followed; $91 \%$ were successful and did not require medical assistance, which demonstrated that trained nurses are competent to perform the procedure successfully and with a low rate of adverse events ${ }^{(15)}$.

Although IUD is a safe, efficient and long-term contraceptive method, it is estimated that, worldwide, only $15 \%$ of women of reproductive age in developing countries and $8 \%$ in developed countries use it for reproductive planning ${ }^{(17)}$. A research conducted in Ceará State analyzing 2,410 records of women of childbearing age showed that 602 (25\%) used hormonal methods, followed by the barrier method by 520 (21.5\%) of them, and the least used was IUDs $(42(1,7) \text { of them })^{(18)}$.

One of the characteristics observed in this study was the higher level of education among nulliparous women and, also, among those who opted for IUD use. Similar data were found in a study conducted in the United States, which assessed the characteristics of users of intrauterine devices and other reversible contraceptive methods. It was noted that compared to users of combined oral contraceptives or injectable contraceptives, IUD users had a higher level of education and income ${ }^{(19)}$.

The women who participated in this study reported absence of hormones as a mechanism of action as an advantage of IUDs, and this criterion was the main reason for choosing IUD use. In this regard, the results are similar to those found in a study carried out in Canada, in which it was concluded that the most important reason for choosing such method by nulliparous women was to avoid the side effects of hormonal contraceptives. Furthermore, $63.3 \%$ of participants in the aforementioned study reported having an aversion to hormonal methods ${ }^{(20)}$.

A study of satisfaction with IUD use by adolescents carried out in a health center located in an educational complex in the United States, followed 75 girls aged between 14 and 19 years and who had already had sexual intercourse. Before IUD, they used an oral hormonal contraceptive method and a condom, stating that they chose this method due to its longer duration, effectiveness, lack of hormones and the lack of need to remember the daily intake or before the sexual act. At the end of six months, 68 still had their IUD, four had their IUDs fallen out and three withdrew on request and $65 \%$ said they were satisfied with the method. They choose the school health service, because it was more convenient and free of charge ${ }^{(21)}$.

In a study conducted at a hospital in Pakistan, 1,250 women were followed for six months after IUD insertion in the postpartum period. Of these, 833 (66.6\%) had no complications, however, among the 417 (33.4\%) women who presented, it was observed that the most common complications were menstrual disorders (19\%), leukorrhea (15.4\%), string loss (21.4\%), poor positioning $(1.1 \%)$ and fall out $(6 \%)^{(22)}$. In this regard, in this study, there were no reports of string loss; however, menstrual disorders were the most reported complaints.

In a study conducted at a hospital in India, 600 women who inserted the copper IUD in the immediate postpartum period were followed for six months; 45 (7.5\%) presented some complication after six months being pain ( $1 \%)$, bleeding $(0.7 \%)$, fall out $(0.83 \%)$, string loss (1.2\%), disorders (3.83\%), and $555(92.5 \%)$ had no complications ${ }^{(23)}$. In this context, the results in the studies cited are in line with the findings in this research.

Increased vaginal bleeding and dysmenorrhea were the most reported complaints after return in a study conducted in Brazil. The study compared adherence and the degree of satisfaction in two groups of women using IUDs, a sample of nulliparous women and another of multiparous women. The most common complaint reported by nulliparous women was dysmenorrhea (48.9\%) and, by multiparous women, increased bleeding $(53.4 \%)^{(24)}$.

The most common side effects associated with copper IUD use are increased menstrual flow (menorrhagia), accentuated menstrual cramps (dysmenorrhea) and irregular bleeding, especially in the first three to six months after insertion ${ }^{(7)}$. Thus, the findings in the literature correspond to those found in this study.

There was a case of perforation of a user's endometrium; however, according to $\mathrm{WHO}$ data, this complication is rare ${ }^{(7)}$, and fall out is one of the frequent complications reported in the literature. In a study carried out in Pakistan, fall out rate was $6 \%{ }^{(22)}$. In a study conducted in Brazil, a 9.6\% fall out rate was observed in nulliparous women and $6.8 \%$ in multiparous women ${ }^{(24)}$. Despite fall out frequency being common in other studies, there was only one case of the event, which occurred due to poor positioning.

Concerning IUD removal during the follow-up of 600 women for six months in India, it was found that, among the 37 cases $(6.2 \%)$, the reasons for removal were pain (1.7\%), infection (1, $3 \%)$, bleeding $(1.5 \%)$, fall out (1.3\%), and tubal ligation $(0.3 \%)$; thus, the IUD continuation rate after six months was $93.8 \%{ }^{(23)}$.

A study carried out at Columbia University Medical Center in New York, United States, followed 199 women who received an IUD for one year. There were 21 removal requests and 7 fall outs; the reasons for requesting removal were dysmenorrhea, irregular bleeding, and desire for pregnancy. It is worth mentioning that the continuity rate was at $85.9 \%{ }^{(25)}$.

Concerning continued use of copper IUDs at the end of the study, it was observed that it was $85.5 \%$, similar to other studies, however higher than the one indicated by the WHO world rate, in which about $78 \%$ remain with this for at least 12 months ${ }^{(26)}$.

\section{Study limitations}

The limitations of this study refer to the fact that the research sample is restricted to only one place of investigation. Another point to be raised refers to the scarcity of national studies on the insertion of this method by nurses.

\section{Contributions to nursing, health, and public policies}

This investigation contributes to discuss copper IUD insertion by nurses, which is not yet consolidated in the country and is in constant discussion about its legality, although the findings in Brazil and worldwide demonstrate successful experience of such practice. Attention is drawn to the nurses' preparation when inserting the device; thus, through training, they will be able to assist in expanding the offer of this method, reducing the rates of unplanned pregnancies and in the implementation of public policies aimed at women's health care. 


\section{CONCLUSIONS}

Considering the proposed objective, the study reached its purpose; the results achieved demonstrated that the majority adapted well to IUDs, which reveals good acceptance by this group and is a free option of long-term contraceptive method; although there are some complications the same ones are common to the literature.

Although IUDs have numerous benefits, they are not without complications or failures; as demonstrated, there are cases of fall out, removal due to poor positioning, poor adaptation and risk of endometrium perforation. However, there was no contraceptive failure in either case, in addition. The greatest advantages of using this method are related to the long duration of the contraceptive effect, as it is a non-hormonal method and prevents failure to forget administration.
IUD use has a high approval rate among users and among those who experienced complications and who could discontinued use; some refer to the desire to try to insert it again. It was observed that after 12 months of follow-up, most users continued with the method and said they were satisfied, revealed the desire for continued use, recommending the method to other women. The complications observed over a year of follow-up occurred in the first six months of use; after that period, adaptation was progressive.

Nurse practitioners are the ones who most perform IUD insertion. Training courses for IUD insertion for nurses at national level and the expansion of social dissemination of this method is necessary, which is available free of charge in health services. Attention is also drawn to the development of studies on this topic in different regions of the country in places where IUD insertion by nurses is consolidated.

\section{REFERENCES}

1. Presidência da República (BR). Lei n. 9.263, de 12 de janeiro 1996. Regula o § $7 \circ$ do art. 226 da Constituição Federal, que trata do planejamento familiar, estabelece penalidades e dá outras providências [Internet]. Diário Oficial da União, Brasília, DF; 1996 [cited 2018 Mar 20]. Jan 15. Seção 1, p. 561. Available from: http://www.planalto.gov.br/ccivil_03/leis/19263.htm

2. Ministério da Saúde (BR). Secretaria de Atenção à Saúde. Departamento de Atenção Básica. Saúde sexual e saúde reprodutiva. Brasília: Ministério da Saúde, 2013. 300 p.

3. Viellas EF, Domingues RMSM, Dias MAB, Gama SGN, Theme Filha MM, Costa JV, et al. Assistência pré-natal no Brasil. Cad Saúde Pública [Internet]. 2014 [cited 2018 Mar 20];30(1):[16 p.]. Available from: http://www.scielo.br/pdf/csp/v30s1/0102-311X-csp-30-s1-0085.pdf

4. Evangelista $C B$, Barbieri M, Silva PLN. Gravidez não planejada e fatores associados à participação em programa de planejamento familiar. Rev Pesqui: Cuid Fundam [Internet]. 2015 [cited 2017 Mar 27];7(2):[11 p.]. Available from: http://www.seer.unirio.br/index.php/ cuidadofundamental/article/view/3633/pdf_1584

5. Ministério da Saúde (BR). Conheça os métodos contraceptivos oferecidos pelo SUS [Internet]. Brasília; 2016 [cited 2018 Mar 28]. Available from: http://www.blog.saude.gov.br/index.php/materias-especiais/51645-saiba-mais-sobre-os-metodos-contraceptivos-oferecidos-pelo-sus

6. Federação Brasileira das Associações de Ginecologia e Obstetrícia. Manual de anticoncepção [Internet]. São Paulo: Federação Brasileira das Associações de Ginecologia e Obstetrícia; 2015 [cited 2017 Mar 27]. Available from: https://armazemdaciencia.files.wordpress.com/2017/08/ manual-anticoncepcao-febrasgo-2015-pdf.pdf

7. World Health Organization (WHO). Department of Reproductive Health and Research (WHO/RHR) and Johns Hopkins Bloomberg School of Public Health/Center for Communication Programs (CCP), Knowledge for Health Project. Family Planning: a global handbook for providers. Baltimore and Geneva: CCP and WHO; 2018.

8. World Health Organization. Medical eligibility criteria for contraceptive use: fifth edition [Internet]. Geneva: World Health Organization; 2015 [cited 2018 Mar. 20]. Available from: http://apps.who.int/iris/bitstream/10665/181468/1/9789241549158_eng.pdf

9. Presidência da República (BR). Lei n. 7.498, de 25 de junho de 1986. Dispõe sobre a regulamentação do exercício da enfermagem, e dá outras providências. Diário Oficial da União, Brasília, DF; 1986 Jun 26. Seção1, p. 9273.

10. Conselho Federal de Enfermagem (Cofen). Resolução n. 358, de 15 de outubro de 2009. Dispõe sobre a Sistematização da Assistência de Enfermagem e a implementação do Processo de Enfermagem em ambientes, públicos ou privados, em que ocorre o cuidado profissional de Enfermagem, e dá outras providências [Internet]. In: Conselho Federal de Enfermagem. Brasília: Cofen; 2009. [cited 2018 Mar 20]. Available from: http://www.cofen.gov.br/resoluo-cofen-3582009_4384.html

11. Conselho Federal de Enfermagem (Cofen). Parecer n. 17, de 11 de novembro de 2010. Trata-se de encaminhamento dos documentos em epígrafe pela Secretaria do Cofen, para análise e emissão de Parecer sobre a "viabilidade dos Enfermeiros realizarem procedimentos com Medicamentos e Insumos para Planejamento Familiar Reprodutivo" [Internet]. In: Conselho Federal de Enfermagem. Brasília: Cofen; 2010[cited 2018 Mar 20]. Available from: http://www.cofen.gov.br/parecer-n-172010-cofen-ctln_6148.html

12. World Health Organization. WHO recommendations: optimizing health worker roles to improve access to key maternal and newborn health interventions through task shifting [Internet]. 2012[cited $2018 \mathrm{Mar} 20$ ]. Available from : https://apps.who.int/iris/bitstream/ handle/10665/77764/9789241504843_eng.pdf?sequence=1

13. Family Planning Association. Your guide to the IUD [Internet]. London: Family Planning Association; 2017. [cited 2018 Sep 26]. Available from: https://www.fpa.org.uk/sites/default/files/intrauterine-device-iud-your-guide.pdf 
14. Kelly PJ, Cheng AL, Carlson K, Witt J. Advanced practice registered nurses and long-acting reversible contraception. J Midwifery Women's Health [Internet]. 2017 [cited 2018 Sep 26];62(2):[6 p.]. Available from: https://onlinelibrary.wiley.com/doi/abs/10.1111/jmwh.12578

15. Kemeny F, Digiusto E, Bateson D. Insertion of intrauterine contraceptive devices by registered nurses in Australia. Australian and New Zealand. J Obstetr Gynaecol [Internet]. 2016 [cited 2018 Sep 26];56(1):[5 p.]. Available from: https://obgyn.onlinelibrary.wiley.com/doi/ pdf/10.1111/ajo.12427

16. Yadav V, Balasubramaniam S, Das S, Srivastava A, Kumar S, Sood B. Comparison of outcomes at 6 weeks following postpartum intrauterine contraceptive device insertions by doctors and nurses in India: a case-control study. Contraception [Internet]. 2016 [cited 2018 Sep 26];93(4):[9 p.]. Available from: https://www.ncbi.nlm.nih.gov/pmc/articles/PMC4796038/pdf/main.pdf

17. D'Arcangues C. Worldwide use of intrauterine devices for contraception. Contraception [Internet]. 2007 [cited 2018 Nov 4];75(6):[6 p.]. Available from: https://www.contraceptionjournal.org/article/S0010-7824(07)00079-0/pdf

18. Ferreira HLOC, Barbosa DFF, Aragão VM, Oliveira TMF, Castro RCMB, Aquino OS, et al. Determinantes Sociais da Saúde e sua influência na escolha do método contraceptivo. Rev Bras Enferm. 2019;72(4):1044-51. doi: 10.1590/0034-7167-2017-0574

19. Xu X, Macaluso M, Frost J, Anderson JE, Curtis K, Grosse SD. Characteristics of users of intrauterine devices and other reversible contraceptive methods in the United States. Fertility and Sterility [Internet]. 2011 [cited 2018 Nov 5];96(5):[7 p.]. Available from: https:// www.fertstert.org/article/S0015-0282(11)02464-2/pdf

20. Wiebe ER, Trouton KJ, Dicus J. Motivation and experience of nulliparous women using intrauterine contraceptive devices. J Obstetr Gynaecol Canada [Internet]. 2010 [cited 2018 Nov 5];32(4):[4 p.]. Available from: https://www.jogc.com/article/S1701-2163(16)34477-2/pdf

21. Stein TB, Summit AK, St. Louis M, Gold M. Patient satisfaction with IUD services in a school-based health center: a pilot study. 2020. doi: 10.1016/j.jpag.2020.01.004

22. Wasim T, Shaukat S, Javed L, Mukhtar S. Outcome of immediate postpartum insertion of intrauterine contraceptive device: experience at tertiary care hospital. J Pakistan Med Assoc [Internet]. 2018 [cited 2018 Sep 26];68(4):[7 p.]. Available from: http://jpma.org.pk/ PdfDownload/8637.pdf

23. Jani PS. Prospective study on outcomes of postpartum intrauterine contraceptive device including safety, efficacy and expulsion at GMERS Medical College, Dharpur-Patan, Gujarat, India. Int J Reproduc, Contraception, Obstetr Gynecol[Internet]. 2018 [cited 2018 Nov 15];7(8):[5 p.]. Available from: http://www.ijrcog.org/index.php/ijrcog/article/download/4992/3724

24. Scavuzzi A, Souza ASR, Amorim MMR. Adesão e grau de satisfação em nuligestas e mulheres com parto anterior usuárias de dispositivo intrauterino. Rev Bras Ginecol Obstet [Internet]. Rio de Janeiro; 2016 [cited 2018 Sep 26];38(3):[8 p.]. Available from: http://www.scielo.br/ pdf/rbgo/v38n3/0100-7203-rbgo-38-03-00132.pdf

25. Maguire K, Joslin-Roher S, Westhoff CL, Davis AR. IUDs at 1 year: predictors of early discontinuation. Contraception [Internet]. 2015 [cited 2020 Jan 30];92(6):575-7. Available from: https://www.ncbi.nlm.nih.gov/pubmed/26365791

26. World Health Organization. Selected practice recommendations for contraceptive use[Internet]. Geneva: WHO; 2016 [cited 2018 Mar 20]. Available from: http://apps.who.int/iris/bitstream/10665/252267/1/9789241565400-eng.pdf 